Article

\title{
Analysis of the Reduction of Pollutant Emissions by the Vehicle Fleet of the City of Reggio Calabria Due to the Introduction of Ecological Vehicles
}

\author{
Concettina Marino $₫$, Cosimo Monterosso $₫$, Antonino Nucara $₫$, Maria Francesca Panzera and \\ Matilde Pietrafesa * \\ Department of Civil, Energetic, Environmental and Material Engineering, University of Reggio Calabria, \\ 89122 Calabria, Italy; concettina.marino@unirc.it (C.M.); cosimo.monterosso92@hotmail.it (C.M.); \\ antonino.nucara@unirc.it (A.N.); francesca.panzera@unirc.it (M.F.P.) \\ * Correspondence: matilde.pietrafesa@unirc.it
}

Received: 4 March 2020; Accepted: 2 April 2020; Published: 4 April 2020

\begin{abstract}
Nowadays, the effects of pollution at a global scale are mainly due to the emissions of greenhouse gases $\left(\mathrm{CO}_{2}\right.$ in particular), especially generated by thermoelectrical plants, as well as the transport, industrial, and civil sectors. Moreover, local pollution effects are generated by several pollutants, such as $\mathrm{CO}, \mathrm{NO}_{\mathrm{x}}, \mathrm{SO}_{\mathrm{x}}, \mathrm{VOC}$, and $\mathrm{PM}$, produced during combustion in transports or building thermal plants. Because of the increasing demand for mobility at an urban scale, pollution caused by transportation plays a significant role. To reduce its environmental impact, a partial or total replacement of old and polluting vehicles with more ecological ones must be urgently implemented. With this aim, in the paper, a detailed analysis of the vehicle fleet of the city of Reggio Calabria (Italy), with reference to passenger cars has been carried out, elaborating four scenarios to reduce their pollutant emissions from 2017 to 2025, both greenhouse gases and local scale ones, through the replacement of old and polluting vehicles with hybrid or electric ones.
\end{abstract}

Keywords: transport; pollutant; gas emissions reduction; vehicle fleet; ecological vehicle

\section{Introduction}

Nowadays, issues concerning environment and pollution are ever-increasing, and many actions have been taken during the last decades by governments around the world in order to reduce the impact of climate change due to greenhouse gas emissions [1-4]. Significant amounts of equivalent $\mathrm{CO} 2$ are mainly produced by the industry [5,6], civil [7,8] and transport sectors [9], particularly, the transport system is responsible for $23 \%$ of total global emissions, contributing with the production of $6.7 \mathrm{GtCO} 2$ [10]. In Italy, from 1990, its increase has been equal to $14.3 \%$ of the final energy used, with consumption in 2016 of 39.1 Mtep, corresponding to 33.7\% of the energy end-use per sector [11].

Among the transport modalities, the road one is the most relevant, corresponding to $84.3 \%$ of the total, with a consumption of fossil fuels equal to $94.9 \%$ and the remaining part covered by biofuel and natural gas [12].

The increasing demand of mobility on-road of people and goods also generates a relevant problem of urban pollution: Pollutants like carbon monoxide (CO), volatile organic compounds (VOC), nitrogen oxides (NOx) and particulate matter (PM) are responsible for high levels of local pollution, particularly in the most crowded cities.

To reduce the environmental impact of on-road transport, a significant change in the vehicle fleet composition should occur, progressively introducing electric and hybrid vehicles, or new technologies like hydrogen systems. 
In the recent years, many actions have been adopted, both at a global and local scale, to promote the reduction of emission percentages, such as the National Strategic Plan for Sustainable Mobility [13], aimed at reaching the objective of $-67 \%$ emissions in the sector within 2050.

Many authors have investigated this issue, such as Santos [14], who discussed the obstacles that prevent transport sector decarbonization, or Hobley [15], who approached the prediction of a possible decarbonization scenario using low emission vehicles, or Philipsen et al. [16], who discussed how important policies and infrastructures are to support the development of new vehicles, electric or hybrid ones, or also Barbieri et al. [17] who considered energy and environmental issues as essential elements for selecting options aimed at reducing $\mathrm{CO}_{2}$ in the Italian transportation sector.

Klein and Smart [18] examined recent changes in auto ownership among US families, with a particular focus on Millennials, whereas Bösch et al. [19] effected an analysis based on costs of automatic mobility services.

Moreover, De Simone et al. [20] dealt with the impact of older vehicles on local environment, whereas Puchalka et al. [21] measured the pollutant exhaust emission of aftermarket vehicles. Marino et al. [22] introduced a new indicator to evaluate urban emissions, Yearly Average Vehicle (YAV) and Vaskina et al. [23] promoted a mathematical model of emission distribution in the roadside ecosystem.

In this frame, the aim of this paper is to simulate different emission reduction scenarios, hypothesizing the partial replacement of old and polluting vehicles (passenger cars) and proposing an application to the city of Reggio Calabria (Italy).

The study represents an important, although partial, contribution to the assessment of obtainable reductions of pollution caused by the transportation sector. Existing knowledge on the topic present in the literature is in fact mainly addressed to policies and scenarios mainly involving the whole or specific components of countries' vehicle fleets, biofuels, or less polluting vehicles [24-26]: Additional knowledge provided by the present study is a detailed methodology of analysis on the emission assessment of each vehicle fleet category, starting from a disaggregated fleet classification with respect to the fuel, the engine power, and the emission class (Euro).

A complete approach to the assessment of the sector environmental impact should anyway consider both the carbon footprint of the whole life-cycle connected with the manufacturing of the less polluting vehicles to be introduced in the car fleet in substitution of the most polluting ones that are removed [27] and the sustainable disposal of the latter, that is both beyond the scope of the present study. Further important aspect to be considered in a comprehensive analysis of the process carbon footprint concerns the source and the efficiency of the power generation of additional electricity that needs to be generated to charge electric vehicles and that, in order to reduce pollution, should exploit the maximum available rate from renewable energy sources, together with the associated problems connected with its distribution (use of smart grids) [28].

\section{Methodology of Analysis}

The methodology used in the study to calculate the emissions of the car fleet of Reggio Calabria is taken from the guidelines EMEP/EEA Air Pollutant Emission Inventory Guidebook 2016 by EEA [29], which also provide a transport emissions database useful for the evaluation of the effects of reduction policies.

The utilized approach, Tier 2, considers both the fuel used by the vehicle categories and its emission factors, which, in Tier 2 are referred to both fuel and pollutants, whereas Tier 3 also refers to the speed values.

In the study, the classification of the car fleet has been made, referring to three parameters:

- the vehicle emission class, referring to European Standards (from Euro 0 to Euro 6) (Table 1)

- the engine capacity $(<1400 \mathrm{~L}, 1400-2000 \mathrm{~L},>2000 \mathrm{~L})$

- the fuel (petrol, diesel, LPG, CNG, or hybrid). 
For each vehicle, the reference legislation is reported in Table 2. The data on transport statistics have been taken from the national Eurostat database [30].

Table 1. Emission classes and related European Standards.

\begin{tabular}{cc}
\hline Emission Class & European Directive \\
\hline Euro 0 or Pre Euro & Vehicles before 31 December 1992 \\
Euro 1 & Directive 91/441 \\
Euro 2 & Directive 94/2012 \\
Euro 3 & Directive 98/69 \\
Euro 4 & Directive 98/69B \\
Euro 5 & Directive 2006/51/CE \\
Euro 6 & Directive 2011/566/CE \\
\hline
\end{tabular}

Table 2. Vehicle classification per fuel and related norm.

\begin{tabular}{|c|c|c|}
\hline $\begin{array}{l}\text { Vehicle } \\
\text { Category }\end{array}$ & Type & Legislation/Technology \\
\hline \multirow{9}{*}{$\begin{array}{c}\text { Passenger } \\
\text { cars }\end{array}$} & Petrol mini & Euro 4, Euro 5, Euro 6 \\
\hline & Petrol Small, Medium, Large-SUV-Executive & $\begin{array}{l}\text { PRE ECE, ECE 15/00-01, ECE 15/02, ECE 15/03, ECE 15/04, } \\
\text { Improved Conventional, Open-Loop Euro 1-Euro } 6 \text { 2020+ }\end{array}$ \\
\hline & Diesel mini & Euro 4, Euro 5, Euro $62020+$ \\
\hline & Diesel Small, Medium, Large-SUV-Executive & Conventional, Euro 1-Euro 6 2020+ \\
\hline & LPG mini & Euro 4, Euro 5, Euro 6 \\
\hline & LPG Small, Medium, Large-SUV-Executive & Conventional, Euro 1-Euro 6 \\
\hline & 2-stroke & Conventional \\
\hline & Petrol Hybrids & Euro 4, Euro 5, Euro 6 2020+ \\
\hline & CNG & Euro 4, Euro 5, Euro 6 \\
\hline
\end{tabular}

The examined pollutants are:

- Carbon monoxide, $\mathrm{CO}$

- Non-methane volatile organic compounds, NMVOC

- Nitrogen oxides, $\mathrm{NO}_{\mathrm{x}}$

- Nitrogen protoxide, $\mathrm{N}_{2} \mathrm{O}$

- Ammonia, $\mathrm{NH}_{3}$

- $\quad$ Particulate Matter, $\mathrm{PM}_{2.5}$

- Carbon dioxide, $\mathrm{CO}_{2}$

Per each jth pollutant, the emission factor has been obtained as follows:

$$
F E_{j}=\left[F E_{f u e l, j} \times F C_{d, j}\right]+F E_{l u b, j}
$$

where:

- $\quad \mathrm{FE}_{\mathrm{j}}$ emission factor for the jth pollutant $(\mathrm{g} / \mathrm{km})$

- $\quad \mathrm{FE}_{\text {fuel, } \mathrm{j}}$ emission factor of the jth pollutant (g/g fuel)

- $\quad \mathrm{FC}_{\mathrm{d}, \mathrm{j}}$ consumption factor of the fuel per $\mathrm{km}$ ( $\mathrm{g}$ fuel $/ \mathrm{km}$ )

- $\mathrm{FE}_{\mathrm{lub}, \mathrm{j}}$ emission factor due to the combustion of lubricating oil $(\mathrm{g} / \mathrm{km})$

The emissions are then calculated using the expression:

$$
E_{t}=\sum_{j}\left[F E_{j} \times d \times c \times n\right]
$$

where:

- $\quad E_{t}$ total emissions ( $\left.t\right)$

- $\quad \mathrm{FE}_{\mathrm{j}}$ emission factor $(\mathrm{g} / \mathrm{km})$ 
- $\mathrm{d}$ average distance yearly covered, $11.000 \mathrm{~km}(\mathrm{~km})$ (International Car Distribution Program [31])

- c conversion factor $\left(10^{-6}\right.$ for $\mathrm{CO}_{2}$ and $10^{-3}$ for the other pollutants)

- $\mathrm{n}$ number of vehicles belonging to the class.

\section{Analysis of the Vehicle Fleet}

\subsection{The Italian Case}

Starting from the Italian database (Automobile Club Italia (ACI)) [32], classification of the vehicle fleet has been made, referring to the year 2017, the most recent year for which complete data have been available. In the analysis, only passenger cars have been considered, excluding light and heavy goods vehicles, buses, and motorcycles. On 31 December 2017, the total number of cars circulating in Italy was 38.520.321. Their classification was obtained combining the type of fuel, the engine power, and the emission class, referring to European Standards.

In Figure 1, the percentage classification per type of fuel is reported, comparing the situation in Italy and per macro area (North, Centre, and South). It can be observed how $91 \%$ of the Italian car fleet is composed of vehicles powered by petrol (44\%) and diesel $(47 \%)$, with low percentages $(9 \%)$ of hybrid or bi-fuelled cars.

Figure 2 shows the fleet classification per emission class and fuel. It can be noticed that in Euro 0, Euro 1, Euro 2 classes there is a high presence of petrol vehicles, while from Euro 3 a significant increase in diesel vehicles occurs, becoming more numerous than the petrol ones.

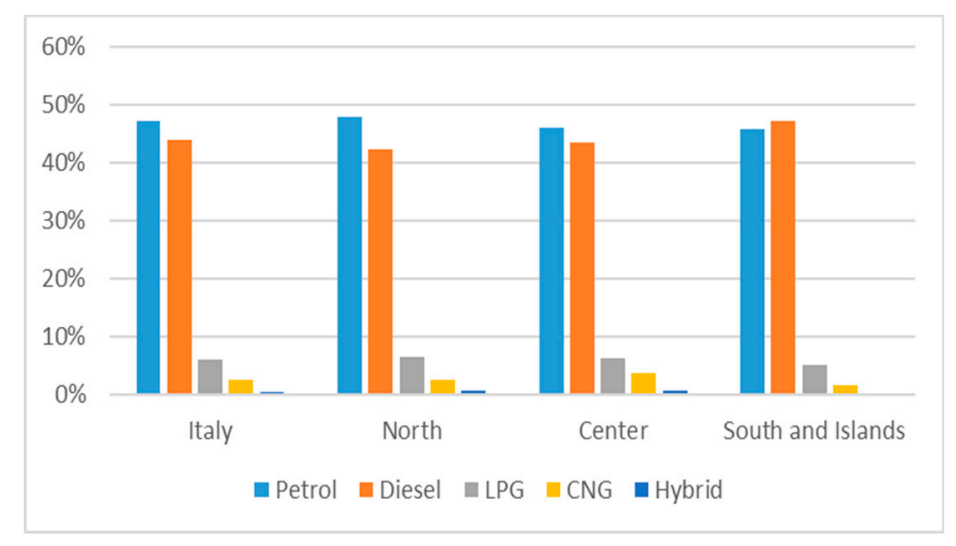

Figure 1. Classification per type of fuel and location [26].

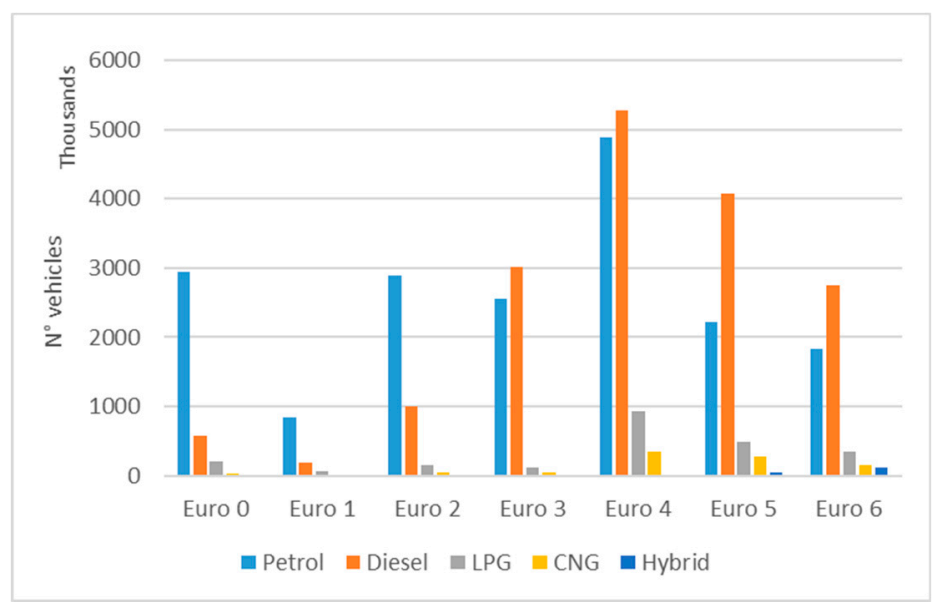

Figure 2. Classification per fuel and emission class [26]. 
Low Impact Vehicles: Hybrid, Electric, and Hydrogen Ones

Vehicles with low environmental impact can be divided into:

- hybrid cars (heat engine plus electric motor)

- $\quad$ pure electric cars (battery operated)

- hydrogen cars, composed of two categories:

$\checkmark \quad$ internal combustion

$\checkmark \quad$ fuel cells

Hybrid cars exploit two different technologies:

(a) with interacting engines: In which part of thermal energy produced by the petrol engine is converted into electricity to supply the batteries

(b) with interacting motors, plug-in version: Equipped with batteries rechargeable via electric cable, with greater autonomy.

Pure electric cars are the battery-powered electric ones: They exclusively use the electric motor, taking energy from the batteries (the most used of which are lithium-ion ones of 24-30 kWh).

As concerns hydrogen cars, the first category uses gas as a fuel in traditional internal combustion heat engines, where only a few changes are implemented to be adapted to hydrogen combustion:

1. reprogram of the control unit to adapt the injection pressure and other gas ignition parameters

2. insertion of sensors to prevent gas self-combustion during suction

3. elimination of turbulence in the combustion chamber (favorable in traditional engines, but unwanted in hydrogen ones).

Hydrogen combustion advantages with respect to traditional fuels (petrol, diesel, LPG, CNG) are:

- use of very lean mixtures (air in excess in the stoichiometric ratio air/fuel) with lower emissions

- more complete combustion

- lower combustion temperature, with faster ignition

- high self-ignition temperature

- higher combustion ratio and consequently efficiency

- more constant efficiency.

Electric cars with hydrogen fuel cells are an evolution of pure electric cars, overcoming problems of large battery pack space and long charging times. Usually, the traction architecture is hybrid, simultaneously using both fuel cells to produce direct current and batteries to which they ensure recharging. Batteries mainly supply the current required for traction, guaranteeing a better system capacity to respond to the transient operation (acceleration, braking, etc.), and thus, a longer life to the fuel cell.

A methane, petrol, diesel, ethanol, and methanol car can also produce hydrogen on-board through reformers installed in the car. Although this solution uses fuel more efficiently $(40 \mathrm{~km} / \mathrm{L})$ than a traditional heat engine, fuels deriving from hydrocarbons, generating emissions even if low, are still used.

\subsection{Case Study: The City of Reggio Calabria}

Figure 3 reports the classification of passenger car fleet of Reggio Calabria in 2017 per engine power, emission class, and fuel. For cars with low engine powers, the impact of petrol vehicles is high for all the classes (especially for the Euro 0 one), except for Euro 4, where the presence of diesel vehicles is relevant. With the increasing engine power, the presence of diesel vehicles increases, representing the category's greatest part. 


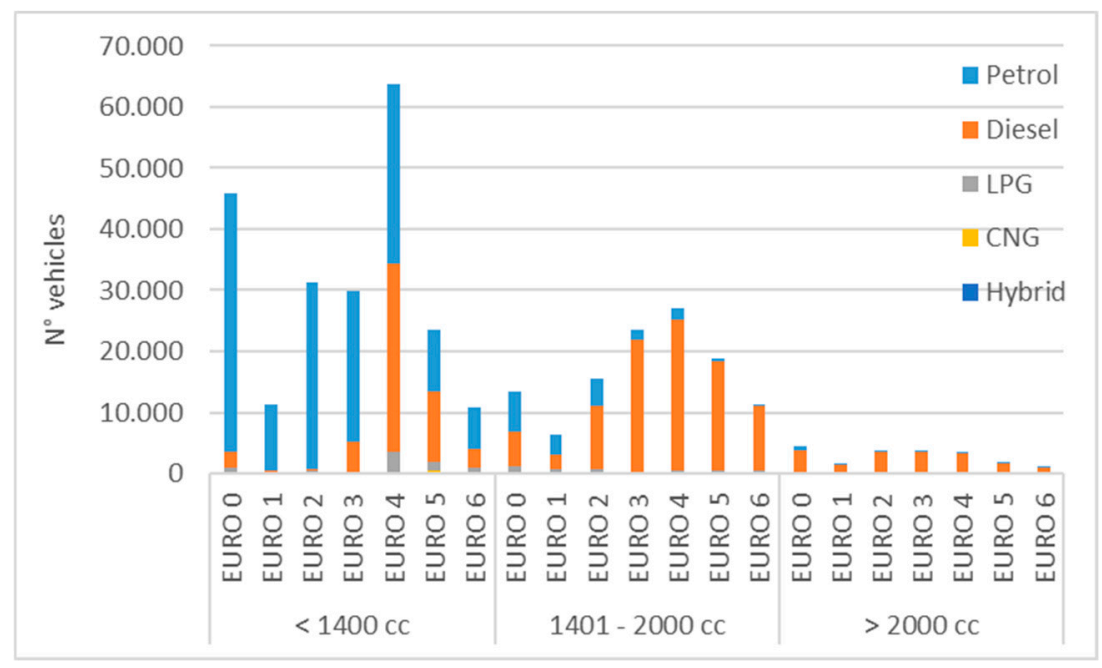

Figure 3. Classification per emission class and fuel [26].

\section{State of Art of Emissions}

The emissions of the car fleet of Reggio Calabria in 2017, subdivided per emission class and fuel type, obtained using Equations (1) and (2), are reported in Figure 4, whereas Figure 5 shows the percentage contribution of the different fuels to the various pollutant emissions.

As emission factors by EEA are not present until Euro 4 class for vehicles fuelled by diesel, with engine power $<1400 \mathrm{~L}$, in the analysis those referring to the class 1400-2000 $\mathrm{L}$ have been used.

Apart from $\mathrm{PM}_{2.5}$, emission factors of all the pollutants are greater for diesel than for petrol. Moreover, they increase as engine power does.

For all the pollutants, the most emitting category is that with engine power $<1400 \mathrm{~L}$, more numerous, mainly fuelled by petrol, except for $\mathrm{PM}_{2.5}$ to which both diesel and power 1400-2000 L give the greatest contribution (Figure 4).

Apart from $\mathrm{NH}_{3}$ and $\mathrm{PM}_{2.5}$, emissions from Euro 0 class are particularly relevant. Euro 4 is responsible for high emissions of $\mathrm{N}_{2} \mathrm{O}, \mathrm{PM}_{2.5}$, and $\mathrm{CO}_{2}$ and Euro 2 for $\mathrm{NH}_{3}$.

Concerning the polluting effect of the different fuels, Figure 5 shows that petrol is significantly responsible for $\mathrm{CO}, \mathrm{NMVOC}$, and $\mathrm{NH}_{3}$ pollution, half-half with gasoline for the emissions of $\mathrm{CO}_{2}$, $\mathrm{NO}_{x}$, and $\mathrm{N}_{2} \mathrm{O}$ and only to a low extent, $\mathrm{PM}_{2.5}$. Emissions of vehicles with different fuels are instead very low.
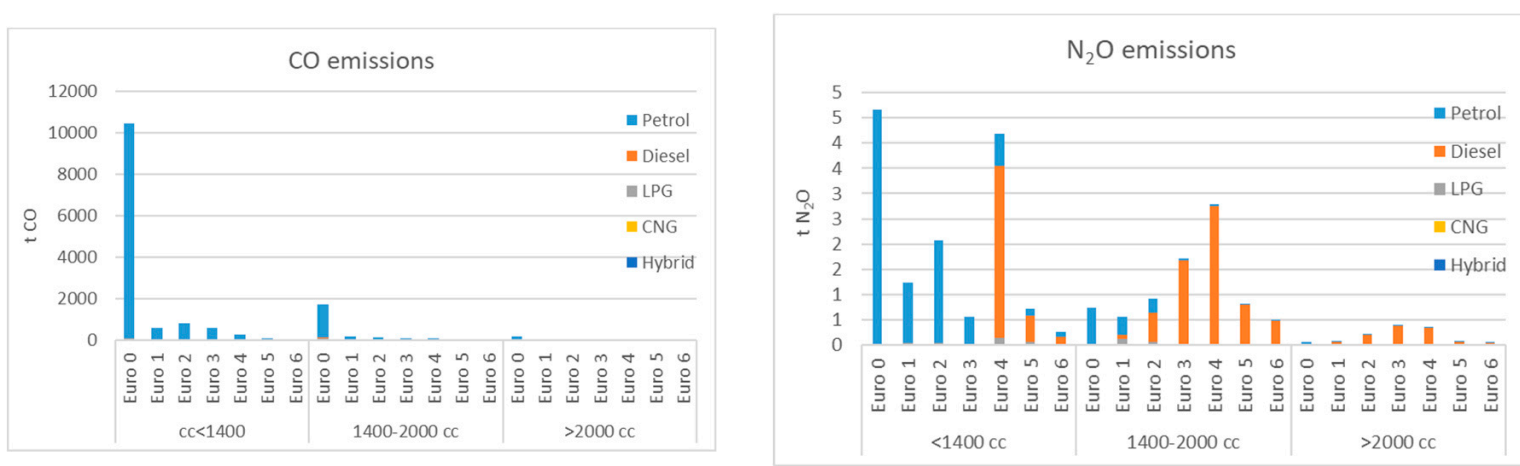

Figure 4. Cont. 

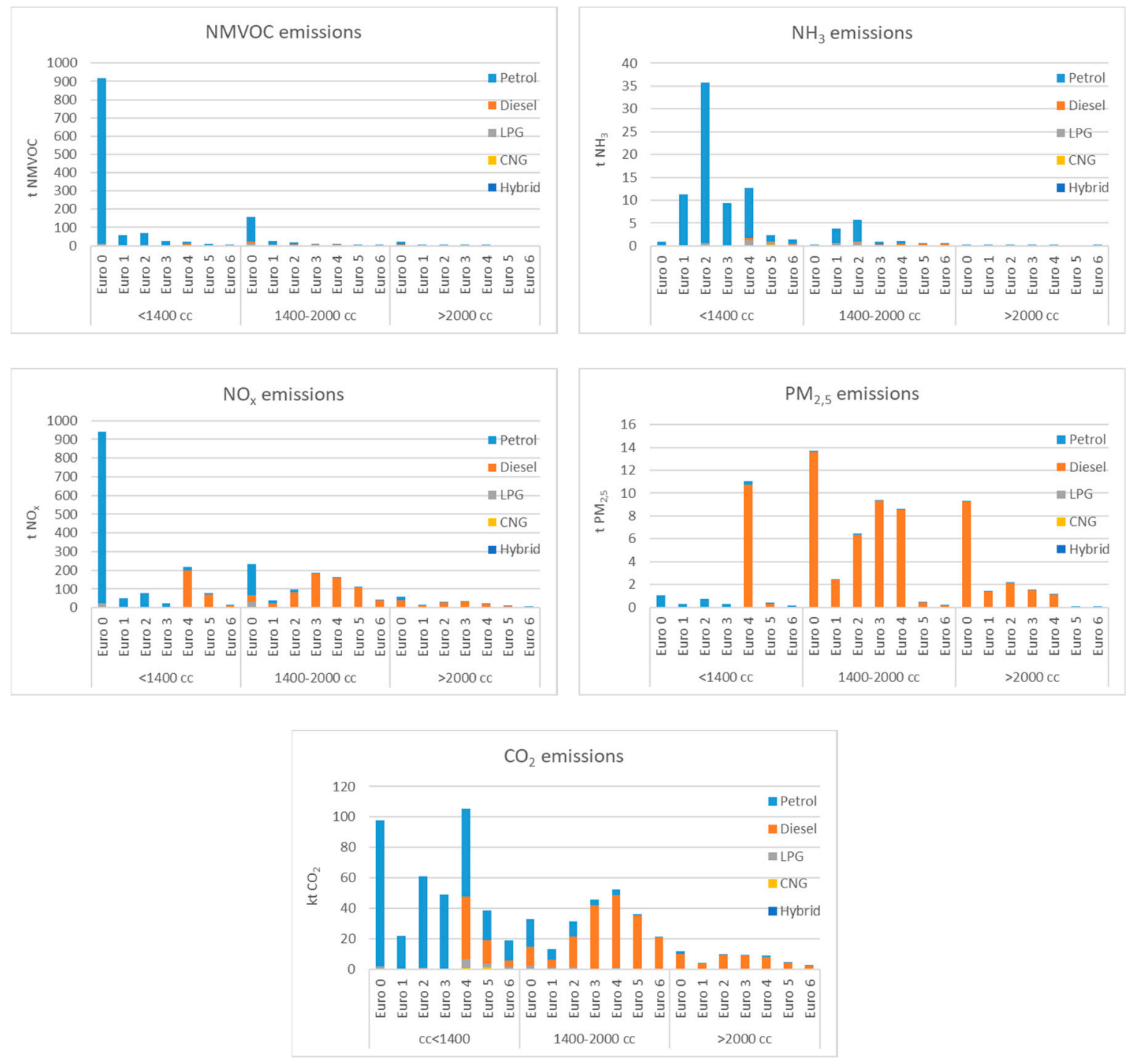

Figure 4. Pollutant emissions per emission class and engine power.

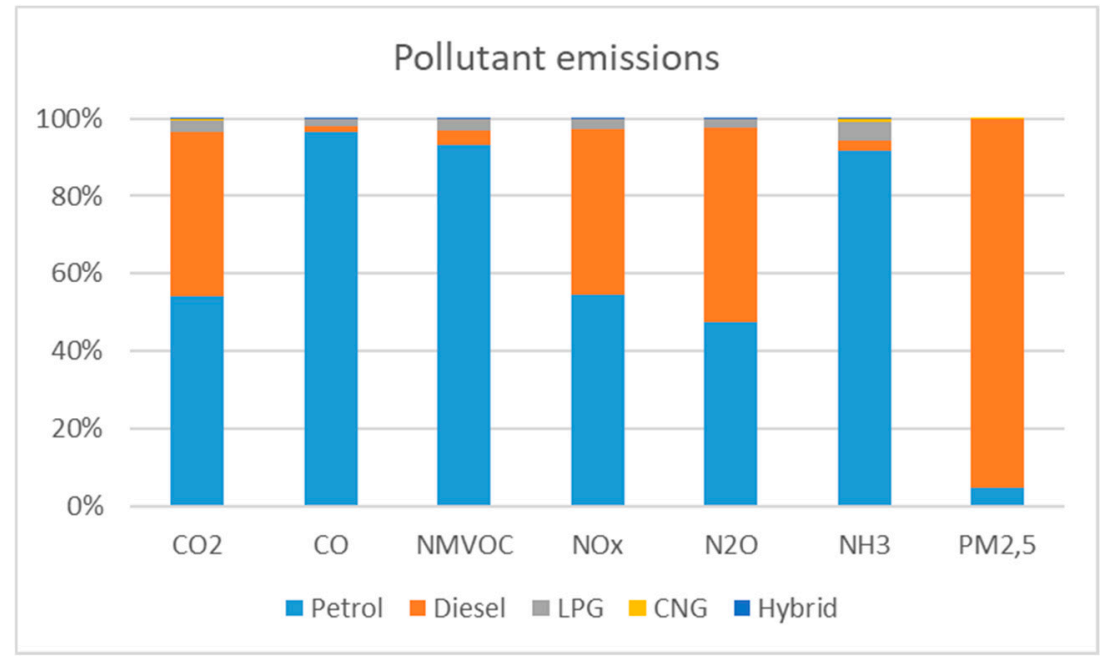

Figure 5. Emissions of the main pollutants. 


\section{State of Art of Emissions}

To reduce the pollutant emissions of the car fleet of Reggio Calabria, four different scenarios have been proposed for 2025, hypothesizing a partial replacement of polluting vehicles. The year 2025 has been selected as a target for the study as the Regulation EU 2019/631 [33], setting new EU fleet-wide $\mathrm{CO}_{2}$ emission performance standards both for newly registered passenger cars and newly registered vans, adding new targets for that year.

\subsection{Scenario 1: Inertial}

The first analyzed scenario is the inertial one: In this aim, the increasing/decreasing vehicle trend, for each fuel, emission, and power engine class has previously been determined, with reference to an equal number of years previous to 2017.

The analysis showed that the total number of vehicles increase of $6,5 \%$, with a distribution more inclined to diesel cars: In 2025, a $+8 \%$ for diesel ones will result in parallel with a $-9 \%$ of petrol ones. A slight increase is also observed for the other fuel classes (Table 3).

Table 3. Vehicle distribution per fuel in 2017 and 2025 (Scenario 1).

\begin{tabular}{ccc}
\hline & \multicolumn{2}{c}{ Vehicle Distribution (\%) } \\
\cline { 2 - 3 } & $\mathbf{2 0 1 7}$ & $\mathbf{2 0 2 5}$ \\
\hline Petrol & 49.6 & 40.6 \\
Diesel & 46.9 & 54.8 \\
LPG & 2.9 & 3.4 \\
CNG & 0.4 & 0.7 \\
Hybrid & 0.2 & 0.5 \\
\hline
\end{tabular}

In Figure 6, the vehicle percentage reduction/increase per class is reported: A significant decrease can be observed for the classes Euro 0-Euro 4, mainly for petrol and diesel vehicles, and a marked increase for the classes Euro 5-Euro 6.

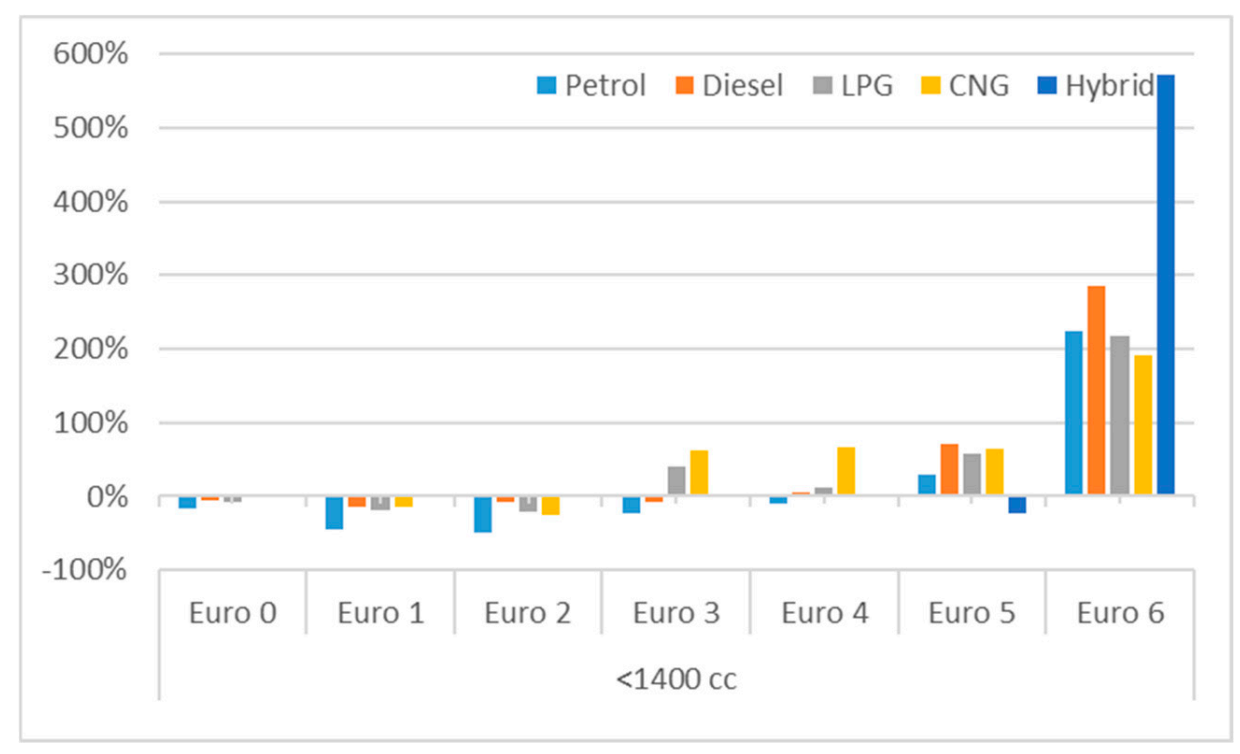

Figure 6. Cont. 

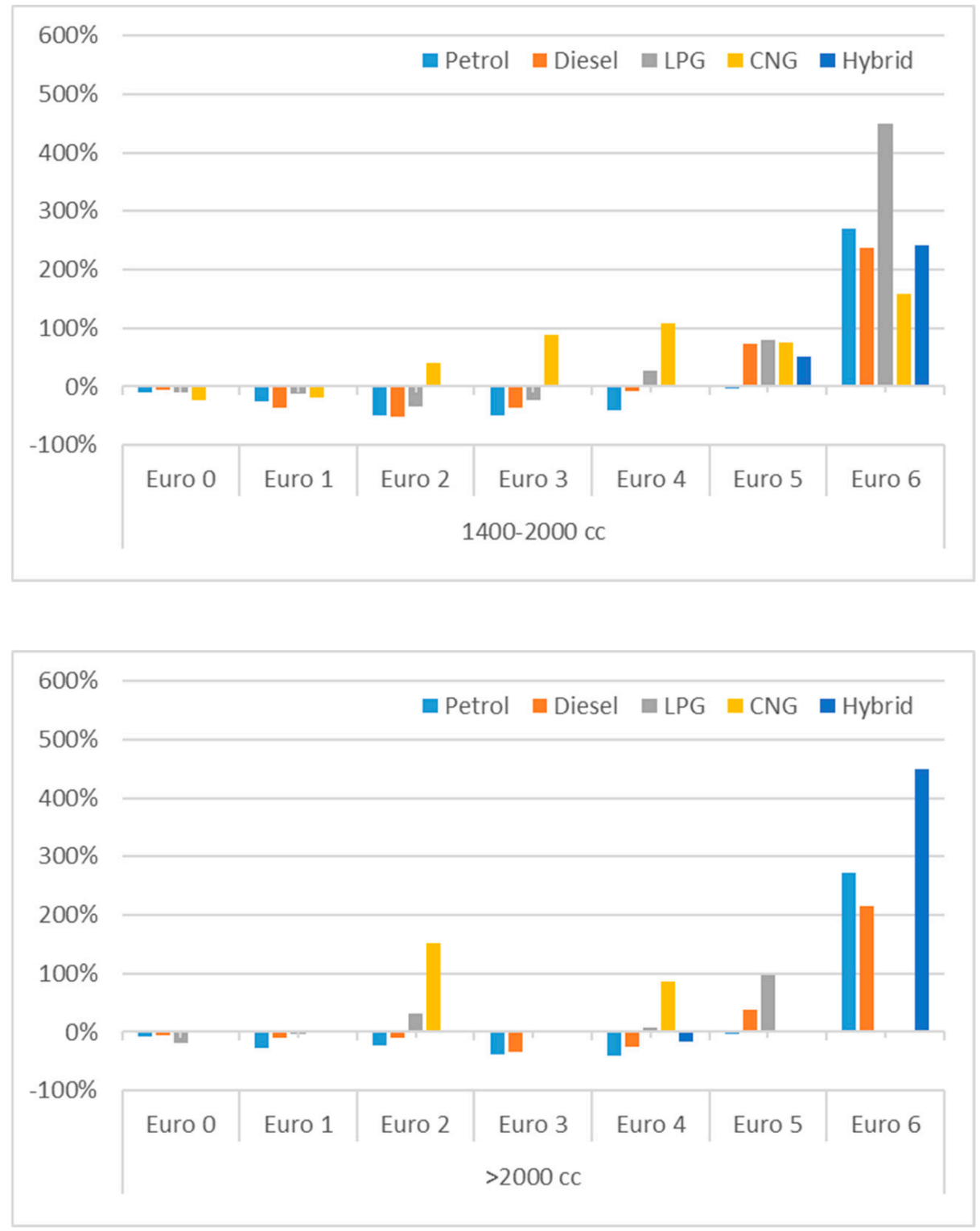

Figure 6. Vehicle reduction/increase per class in 2025 (Scenario 1).

\subsection{Scenario 2: Partial Replacement of Petrol and Diesel Vehicles with Change of Fuel}

The second scenario effects a vehicle substitution in the most pollutant fuel classes (petrol and diesel), addressing them to the LPG, CNG, and hybrid ones: In this aim, their yearly scrapping rate (6800 vehicles/year) has been adopted, together with their mean increase (2750/year) (ACI database) (Table 4).

Table 4. Vehicle distribution per class in 2025 (Scenario 2).

\begin{tabular}{ccc}
\hline & \multicolumn{2}{c}{ Vehicle Distribution (\%) } \\
\cline { 2 - 3 } & $\mathbf{2 0 1 7}$ & $\mathbf{2 0 2 5}$ \\
\hline Petrol & 49.6 & 39.4 \\
Diesel & 46.9 & 37.9 \\
LPG & 2.9 & 15.1 \\
CNG & 0.4 & 3.8 \\
Hybrid & 0.2 & 3.8 \\
\hline
\end{tabular}


The substitution percentages have been distributed among the fuel classes respecting the actual distribution of the fleet (Table 5). Diesel and petrol cars present $10 \%$ reduction, while LPG, CNG, and hybrid ones, respectively, increase $+13 \%,+3,4 \%,+3,6 \%$ (including increments).

Table 5. Vehicle distribution per fuel and engine power.

\begin{tabular}{cccc}
\hline & $<\mathbf{1 4 0 0}$ (cc) & $\mathbf{1 4 0 0 - 2 0 0 0 ~ ( c c ) ~}$ & $>\mathbf{2 0 0 0}$ (cc) \\
\hline Petrol & $89 \%$ & $10 \%$ & $1 \%$ \\
Diesel & $32 \%$ & $57 \%$ & $11 \%$ \\
LPG & $67 \%$ & $31 \%$ & $2 \%$ \\
CNG & $86 \%$ & $13 \%$ & $1 \%$ \\
Hybrid & $4 \%$ & $84 \%$ & $12 \%$ \\
\hline
\end{tabular}

\subsection{Scenario 3: Partial Replacement of Euro 0-Euro 4 Vehicles Maintaining the Same Fuel}

The third scenario simulates a gradual, constant reduction $(20 \%)$ of the most pollutant classes (Euro 0-Euro 4), substituting their cars with Euro 6 ones, maintaining the same fuel. The number of Euro 5 ones is kept constant.

The distribution obtained, taking into account also the mean yearly increase, is reported in Table 6 .

Table 6. Vehicle distribution per class in 2025 (Scenario 3).

\begin{tabular}{ccc}
\hline & \multicolumn{2}{c}{ Vehicle Distribution (\%) } \\
\cline { 2 - 3 } & $\mathbf{2 0 1 7}$ & $\mathbf{2 0 2 5}$ \\
\hline Petrol & 49.6 & 48.5 \\
Diesel & 46.9 & 45.9 \\
LPG & 2.9 & 3.6 \\
CNG & 0.4 & 1.1 \\
Hybrid & 0.2 & 0.9 \\
\hline
\end{tabular}

\subsection{Scenario 4: Partial, Major Replacement of Euro 0-Euro 4 Vehicles Maintaining the Same Fuel}

The fourth scenario simulates the same conditions as Scenario 3 (the distribution per fuel class at 2025 is the same) but considering significant reduction percentages for the most pollutant classes (Table 7).

Table 7. Vehicle replacement distribution in 2025 (Scenario 4).

\begin{tabular}{cc}
\hline Class & Vehicle Replacement (\%) \\
\hline Euro 0 & 50 \\
Euro 1 & 50 \\
Euro 2 & 50 \\
Euro 3 & 30 \\
Euro 4 & 20 \\
\hline
\end{tabular}

\section{Results and Discussion}

Table 8 reports emission reductions obtained in the four scenarios with reference to the various pollutants.

Table 8. Pollutant emissions reduction (\%).

\begin{tabular}{ccccc}
\hline \multicolumn{5}{c}{ Scenario } \\
\hline Pollutant & $\mathbf{1}$ & $\mathbf{2}$ & $\mathbf{3}$ & $\mathbf{4}$ \\
\hline $\mathrm{CO}_{2}$ & $4 \%$ & $2 \%$ & $3 \%$ & $2 \%$ \\
$\mathrm{CO}$ & $-17 \%$ & $-13 \%$ & $-18 \%$ & $-44 \%$ \\
$\mathrm{~N} V \mathrm{NOC}$ & $-17 \%$ & $-11 \%$ & $-18 \%$ & $-45 \%$ \\
$\mathrm{NO}_{\mathrm{x}}$ & $-5 \%$ & $-13 \%$ & $-13 \%$ & $-30 \%$ \\
$\mathrm{~N}_{2} \mathrm{O}$ & $-5 \%$ & $-5 \%$ & $-10 \%$ & $-20 \%$ \\
$\mathrm{NH}_{3}$ & $-28 \%$ & $16 \%$ & $-9 \%$ & $-24 \%$ \\
$\mathrm{PM}_{2.5}$ & $-13 \%$ & $-14 \%$ & $-18 \%$ & $-35 \%$ \\
\hline
\end{tabular}




\subsection{Scenario 1}

In Figure 7, the comparison between the emission of state of the art and its reduction effects produced by Scenario 1 is shown.

From Table 8, it can be observed that the most significant reductions from the initial state occur for $\mathrm{NH}_{3}(28 \%), \mathrm{CO}$ and NMVOC (17\%), and $\mathrm{PM}_{2.5}(13 \%)$, whereas the other nitrogen compounds suffer a lower reduction (5\%). $\mathrm{CO}_{2}$, instead, increases by $4 \%$.

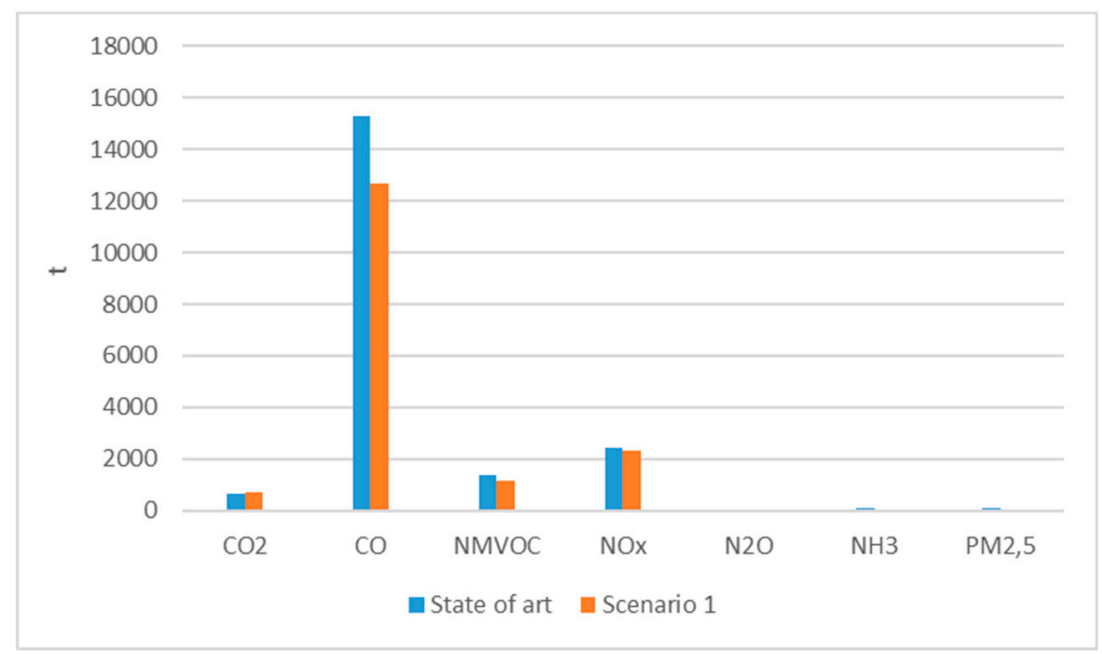

Figure 7. Scenario 1: Emission comparison with state of the art.

\subsection{Scenario 2}

Referring to Scenario 2, Figure 8 shows the observed emission reductions. Light decreases occur for all the gases $(5 \%-14 \%)$ whereas increases are observed for $\mathrm{NH}_{3}(+16 \%)$, due to the higher emission factor of LPG compared with petrol and diesel ones, and $\mathrm{CO}_{2}(+2 \%)$ (Table 8$)$.

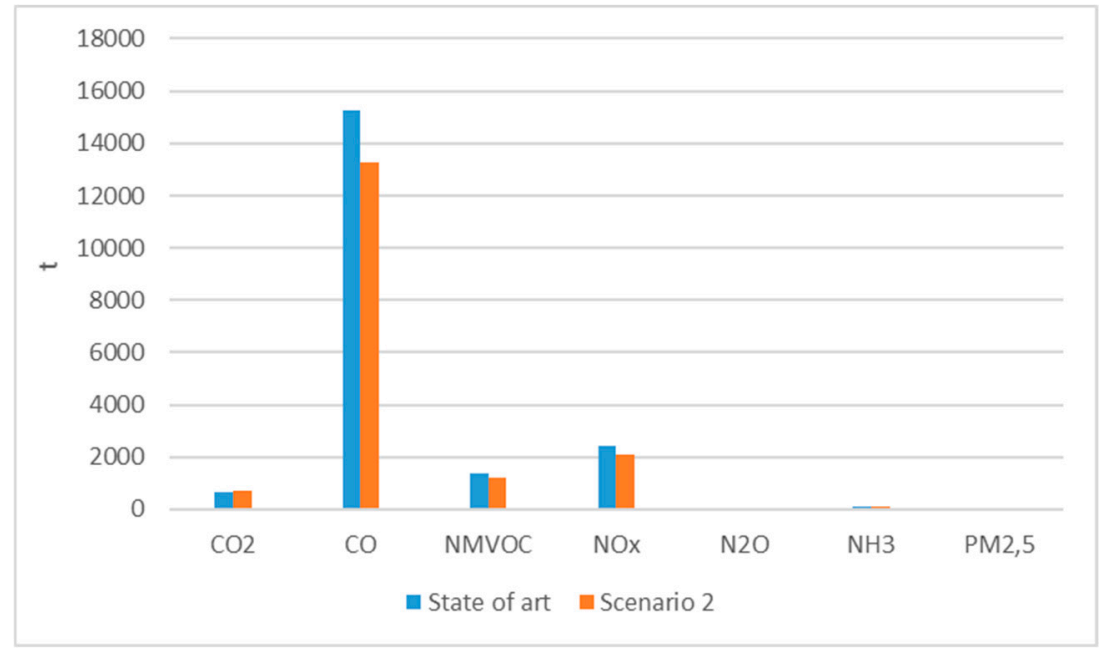

Figure 8. Scenario 2: Emission comparison with state of the art.

\subsection{Scenario 3}

Emission reductions produced by Scenario 3 are reported in Figure 9. This scenario shows major reduction percentages for $\mathrm{CO}, \mathrm{NMVOC}$, and $\mathrm{PM}_{2.5}(-18 \%)$ and lower $(9 \%-13 \%)$ for the nitrogen compounds. $\mathrm{CO}_{2}$ increases by $3 \%$ (Table 8 ). 


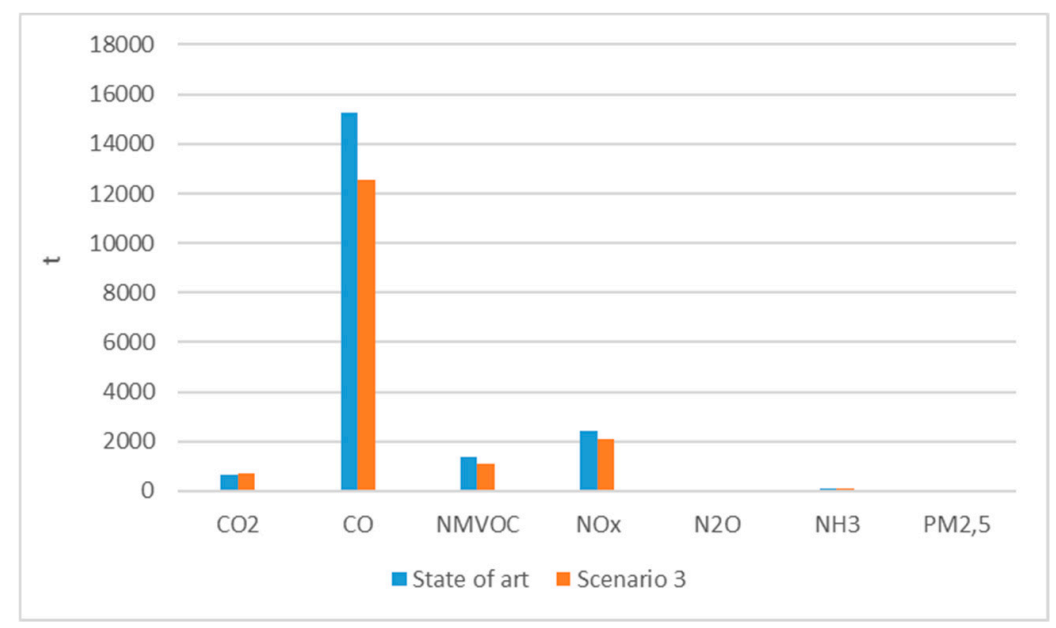

Figure 9. Scenario 3: Emission comparison with state of the art.

\subsection{Scenario 4}

Emission reductions produced by Scenario 4 are reported in Figure 10. The fourth scenario seems the most effective, in particular for CO and NMVOC, for which reductions are $44 \%-45 \%, \mathrm{PM}_{2.5}(35 \%)$ and $\mathrm{NO}_{\mathrm{x}}(30 \%) . \mathrm{N}_{2} \mathrm{O}$ and $\mathrm{NH}_{3}$ decrease is slightly lower (20\%-24\%) (Table 8). Moreover, even in a drastic scenario like the fourth, an increase of $2 \%$ of $\mathrm{CO}_{2}$ occurs.

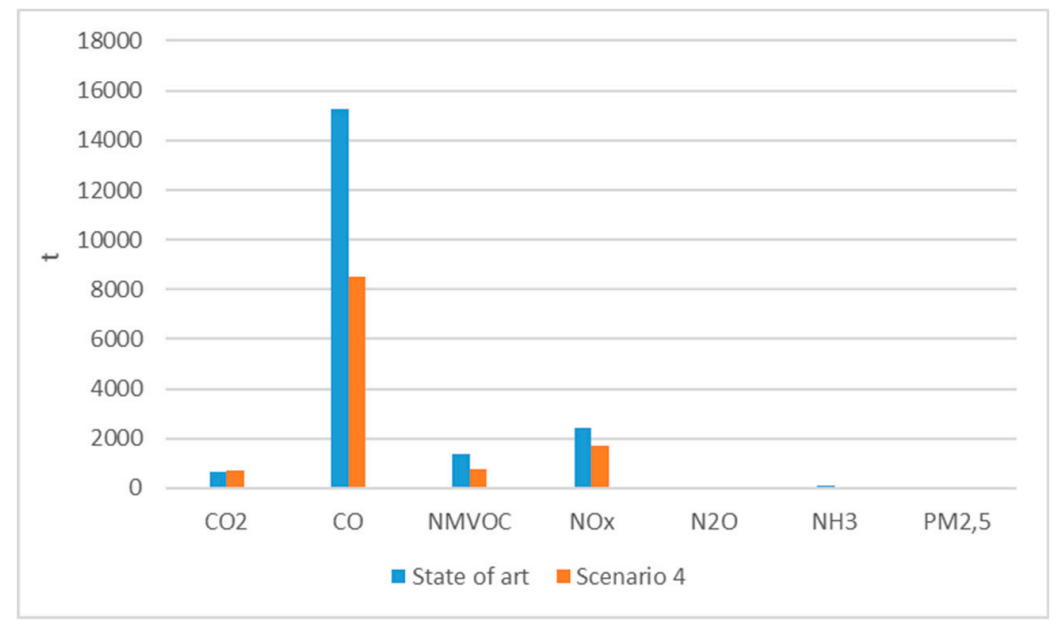

Figure 10. Scenario 4: Emission comparison with state of the art.

\subsection{Scenario 5}

Figures 11-14 show a comparison among emission reductions in the four scenarios, separately for $\mathrm{CO}_{2}$ and the other gases. Particularly, Figures 13 and 14 refer to fuel classes.

As it can be observed, the fourth scenario presents the greatest efficacy, especially in terms of NMVOC and CO, showing reductions double or triple the previous ones. For the other gases (apart $\mathrm{CO}_{2}$ ), the differences among scenarios are lower, varying between 5\% and 18\% (Table 8 ).

Concerning $\mathrm{CO}_{2}$, from Figure 11, it can be observed that its emissions increase in all scenarios, due to the increase in the total number of vehicles. Moreover, Figure 13 points out that $\mathrm{CO}_{2}$ emissions in all scenarios derive in a rather equal way from both petrol and diesel vehicles, apart from Scenario 2, where a strong impact is also due to LPG vehicles, for their number increases.

From the above, it follows that, although for pollutants with local character Scenario 4 provides important emission reductions, in order to match more ambitious objectives consistent with both Italian Energy Strategy [33] and European targets, also less polluting classes of car fleet (from Euro 2 on) 
should be replaced, together with other important categories, such as heavy vehicles, both for goods and passengers (buses).

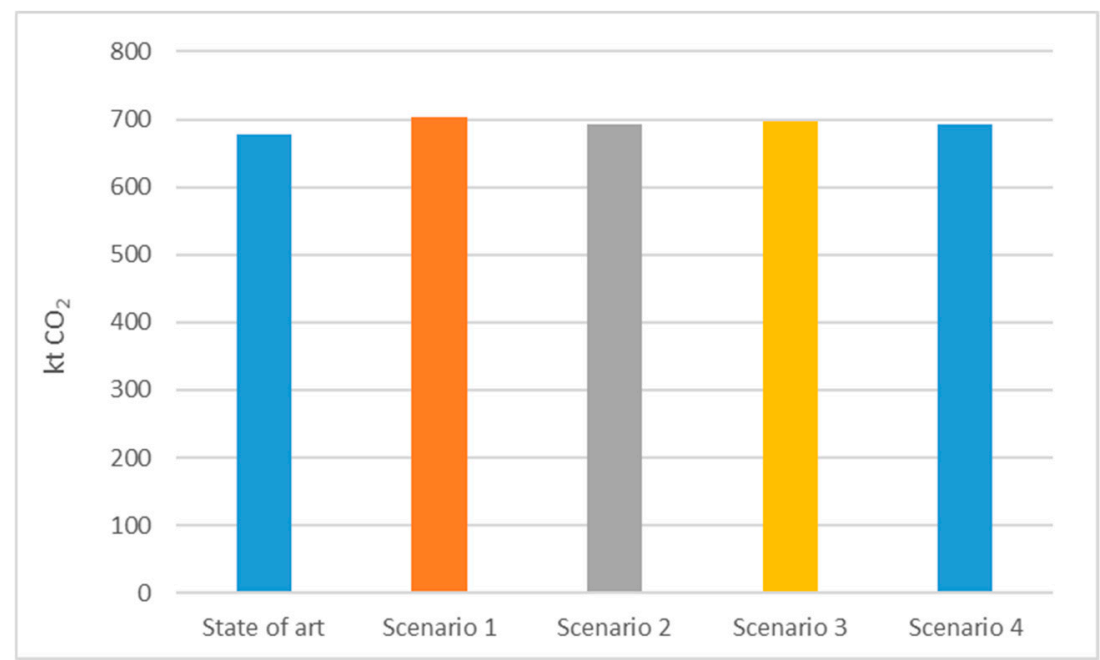

Figure 11. Comparison of $\mathrm{CO}_{2}$ emissions in the scenarios.

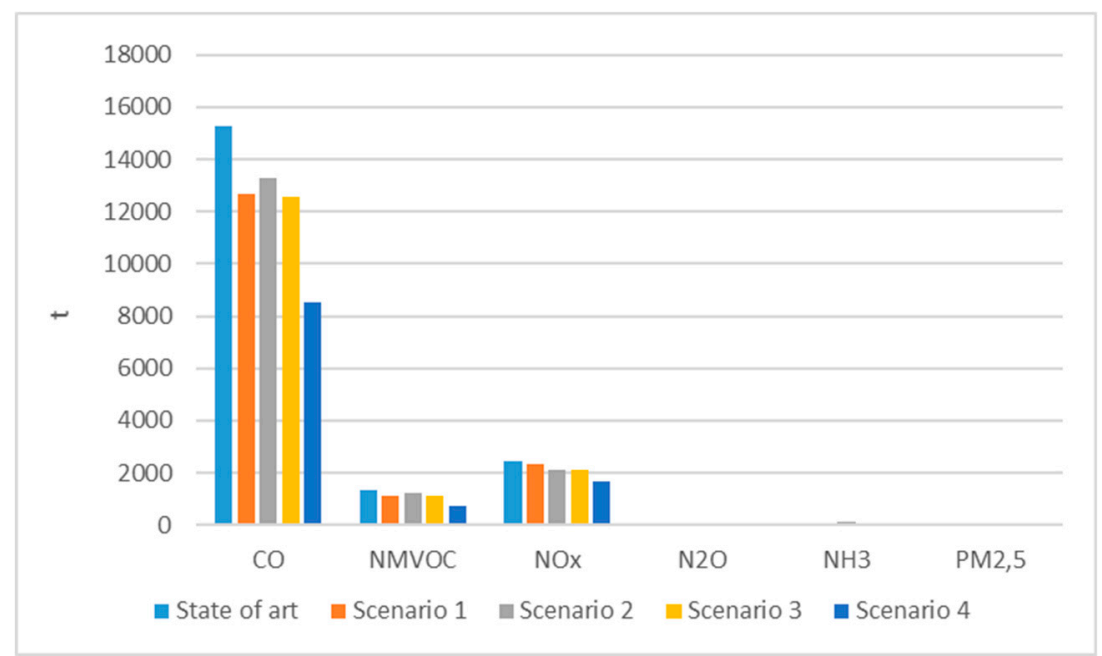

Figure 12. Comparison among emissions in the scenarios (other gases).

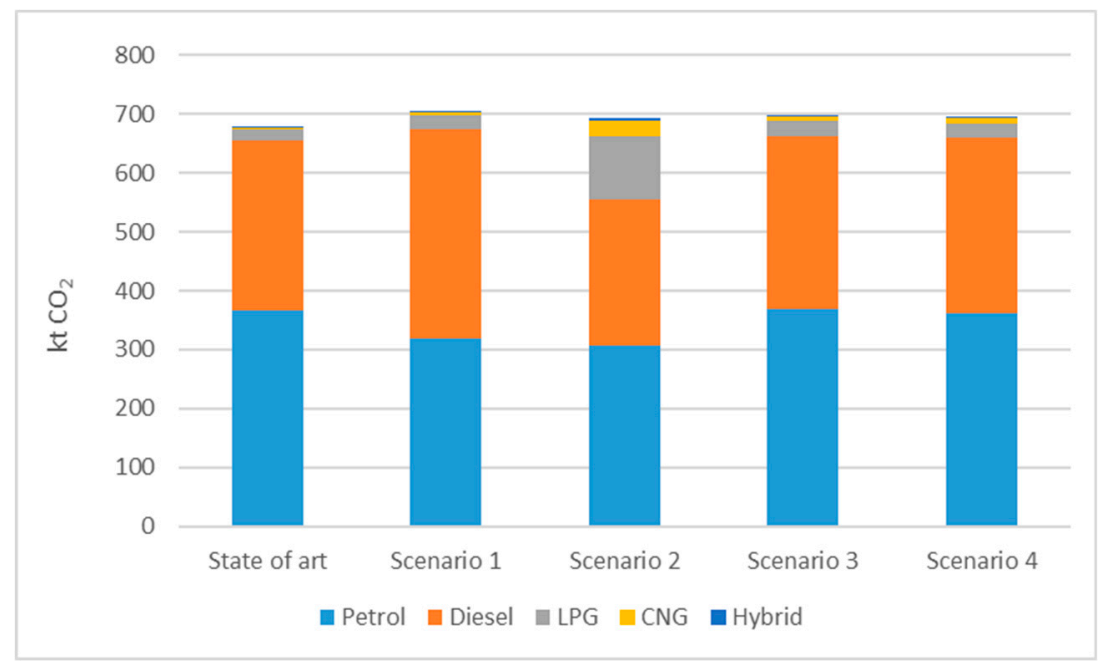

Figure 13. Comparison among $\mathrm{CO}_{2}$ emissions in the scenarios per fuel class. 


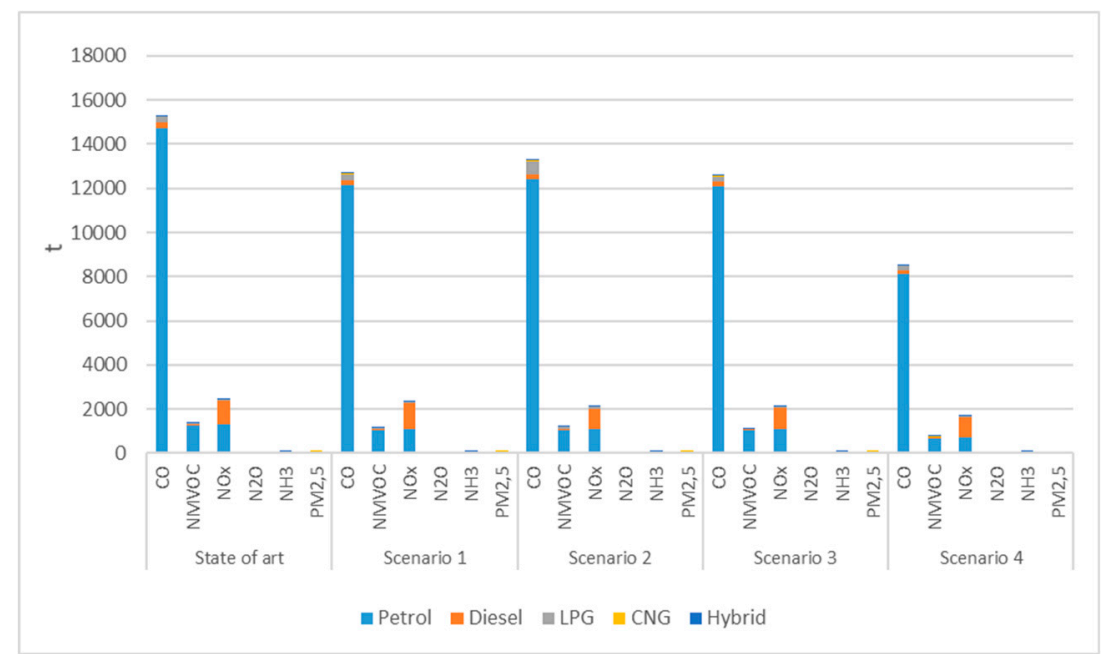

Figure 14. Comparison among emissions of local pollutants in the scenarios per fuel classes.

\section{Conclusions}

In the paper, the emissions of the car fleet of the city of Reggio Calabria (Italy) have been assessed, focusing on the estimation of reductions achievable in consequence of a partial replacement of its most polluting vehicles.

The contribution provided by the present study to existing knowledge on the issue is a detailed methodology of analysis on the emission assessment of each vehicle fleet category, starting from a disaggregated car fleet classification with respect to the type of fuel, the engine power, and the emission class (Euro).

Specific pollutants, both with local (CO, NMVOC, nitrogen oxides, $\mathrm{N}_{2} \mathrm{O}$, and $\left.\mathrm{PM}_{2.5}\right)$ and global effects $\left(\mathrm{CO}_{2}\right)$ have been considered in the analysis.

The classification showed that the number of petrol vehicles is high for low engine powers, especially for the Euro 0 class, and only in Euro 4 one the presence of diesel vehicles is relevant. Their number increases as the engine power does, representing the greatest part of the corresponding classes.

The most emitting power category was that with engine power $<1400 \mathrm{~L}$, more numerous, mainly fuelled by petrol, except for $\mathrm{PM}_{2.5}$ to which both diesel and power 1400-2000 L give the greatest contribution.

Concerning the emission class, emissions from Euro 0 one are particularly relevant, apart from $\mathrm{NH}_{3}$ and $\mathrm{PM}_{2.5}$, whereas Euro 4 is responsible for high emissions of $\mathrm{N}_{2} \mathrm{O}, \mathrm{PM}_{2.5}$, and $\mathrm{CO}_{2}$ and Euro 2 of $\mathrm{NH}_{3}$.

With regard to the fuel, petrol cars seem to be responsible for the major part of $\mathrm{CO}, \mathrm{NMVOC}$, and $\mathrm{NH} 3$, diesel ones for $\mathrm{PM}_{2.5}$, whereas both fuels contribute half-half to $\mathrm{CO}_{2}, \mathrm{NO}_{\mathrm{x}}$, and $\mathrm{N}_{2} \mathrm{O}$ emissions.

To reduce the impact of polluting vehicles on both local and global emissions, four scenarios for 2025 have been hypothesized: One inertial (1), one considering a partial substitution of vehicles of most pollutant classes with ecological ones (2), one with $20 \%$ substitution of most polluting vehicles (from Euro 0-Euro 4 classes), with others less polluting (Euro 6), maintaining the same fuel (3), a fourth analogous to Scenario 3, but with more incisive reductions (4).

From the analysis, the most effective scenario was the fourth one, producing a reduction of $45 \%$ of NMVOC and $44 \%$ of $\mathrm{CO}$ (both triple than those of the first two scenarios), but also significative reductions in $\mathrm{PM}_{2.5}(35 \%)$ and $\mathrm{NO}_{\mathrm{x}}(30 \%) . \mathrm{CO}_{2}$, on the contrary, increases in all scenarios due to the increase of the total vehicle number.

In conclusion, the analysis showed that the presence of hybrid and electric vehicles in the car fleet can significantly contribute to the reduction of local pollution but does not allow $\mathrm{CO}_{2}$ savings if the total car number increases. 
In this aim, an important contribution is given by the administrations with their local policies, that are increasing the number of infrastructures provided by electric rechargeable stations and in the future might also adopt alternative solutions, such as hydrogen stations.

Anyway, in order to match more crucial objectives, particularly at a global scale, the penetration into the fleet of ecological vehicles should also involve replacements of vehicles belonging to less polluting classes. Moreover, the analysis in the future should consider, besides passenger cars, other important fleet categories, such as light and heavy goods vehicles, buses, and motorcycles.

Author Contributions: Data analysis, C.M. (Concettina Marino), emission assessment, C.M. (Cosimo Monterosso), software elaboration, A.N., scenarios definition, M.F.P., supervision, M.P. All authors have read and agreed to the published version of the manuscript.

Funding: This work was carried out within the research project n. 201594LT3F, "Research for SEAP: a platform for municipalities taking part in the Covenant of Mayors", which is funded by the PRIN (Programmi di Ricerca Scientifica di Rilevante Interesse Nazionale) of the Italian Ministry of Education, University and Research.

Conflicts of Interest: The authors declare no conflict of interest.

\section{References}

1. Fraccascia, L.; Giannoccaro, I. Analyzing CO emissions flows in the world economy using Global Emission Chains and Global Emission Trees. J. Clean. Prod. 2019, 234, 1399-1420. [CrossRef]

2. De Macedo, L.S.V.; Jacobi, P.R. Subnational politics of the urban age: Evidence from Brazil on integrating global climate goals in the municipal agenda. Palgrave Commun. 2019, 5, 18. [CrossRef]

3. Vavrek, R.; Chovancovà, J. Assessment of economic and environmental energy performance of EU countries using CV-TOPSIS technique. Ecol. Indic. 2019, 106, 105519. [CrossRef]

4. Ladrech, R.; Little, C. Drivers of political parties' climate policy preferences: Lessons from Denmark and Ireland. Environ. Politics 2019, 28, 1017-1038. [CrossRef]

5. Cui, C.; Shan, Y.; Liu, J.; Yu, X.; Wang, H.; Wang, Z. $\mathrm{CO}_{2}$ emissions and their spatial patterns of Xinjiang cities in China. Appl. Energy 2019, 252, 113473. [CrossRef]

6. Salman, M.; Long, X.; Dauda, L.; Mensah, C.N.; Muhammad, S. Different impacts of export and import on carbon emissions across 7 ASEAN countries: A panel quantile regression approach. Sci. Total Environ. 2019, 686, 1019-1029. [CrossRef]

7. Kamal, A.; Al-Ghamdi, S.G.; Koç, M. Role of energy efficiency policies on energy consumption and CO2 emissions for building stock in Qatar. J. Clean. Prod. 2019, 235, 1409-1424. [CrossRef]

8. Huang, Y.; Liao, C.; Zhang, J.; Guo, H.; Zhou, N.; Zhao, D. Exploring potential pathways towards urban greenhouse gas peaks: A case study of Guangzhou, China. Appl. Energy 2019, 113369. [CrossRef]

9. Kellner, F.; Schneiderbauer, M. Further insights into the allocation of greenhouse gas emissions to shipments in road freight transportation: The pollution routing game. Eur. J. Oper. Res. 2019, 278, 296-313. [CrossRef]

10. Sims, R.; Schaeffer, R.; Creutzig, F.; Cruz-Núñez, X.; D’Agosto, M.; Dimitriu, D.; Meza, M.J.F.; Fulton, L.; Kobayashi, S.; Lah, O; et al. 2014: Transport. In Climate Change 2014: Mitigation of Climate Change. Contribution of Working Group III to the Fifth Assessment Report of the Intergovernmental Panel on Climate Change; Edenhofer, O., Pichs-Madruga, R., Sokona, Y., Farahani, E., Kadner, S., Seyboth, K., Adler, A., Baum, I., Brunner, S., Eickemeier, P., et al., Eds.; Cambridge University Press: Cambridge, UK; New York, NY, USA, 2014.

11. Manduzio, L.; Federici, A.; Moneta, R.; Bertini, I. Annual Report on Energy Efficiency; ENEA: Rome, Italy, 2018.

12. Gracceva, F.; Baldissara, B.; Zini, A.; Colosimo, A. Analisi trimestrale del Sistema energetico italiano; ENEA: Rome, Italy, 2019.

13. Giarandoni, A.; Tu, E.; Chatziathanasiou, M.; Chrysostomou, K.; Alzer, P. Report EU Good Practices on Sustainable Mobility Planning and SUMP; European Union; Interreg Union: Luxembourg, 2018.

14. Santos, G. Road transport and $\mathrm{CO}_{2}$ emissions: What are the challenges? Transp. Policy 2017, 59, 64-71. [CrossRef]

15. Hobley, A. Will gas be gone in the United Kingdom (UK) by 2050? An impact assessment of urban heat decarbonisation and low emission vehicle uptake on future UK energy system scenarios. Renew. Energy 2019, 142, 695-705. [CrossRef] 
16. Philipsen, R.; Brell, T.; Biermann, H.; Eickels, T.; Brost, W.; Ziefle, M. Should I Stay or Should I Go? Influencing Context Factors for Users' Decisions to Charge or Refuel Their Vehicles. Adv. Intell. Syst. Comput. 2020, 964, 573-584. [CrossRef]

17. Barbieri, D.; Nucara, A.; Pietrafesa, M.; Rizzo, G. Energy and environmental issues as choosing elements for selecting options in the transportation sector aimed at reducing CO2 emissions: An application to the Italian case. Stud. Environ. Sci. 1995, 65, 1193-1196. [CrossRef]

18. Klein, N.J.; Smart, M.J. Millennials and car ownership: Less money, fewer cars. Transp. Policy 2017, 53, 20-29. [CrossRef]

19. Bösch, P.M.; Becker, F.; Becker, H.; Axhausen, K.A. Cost-based analysis of autonomous mobility services. Transp. Policy 2018, 64, 66-91. [CrossRef]

20. De Simone, E.; D’Uva, M.; Ercolano, S. Don't save lemons! The impact of older technology vehicles on environmental expenditure at regional level in Italy. Ecol. Indic. 2019, 106. [CrossRef]

21. Puchałka, B.; Szczotka, A.; Nowakowski, J. The Pollutant Emission of the Aftermarket Vehicles. Mech. Mach. Sci. 2020, 70, 61-69. [CrossRef]

22. Marino, C.; Nucara, A.; Pietrafesa, M.; Pudano, A. The Assessment of Road Traffic Air Pollution by Means of an Average Emission Parameter. Environ. Modeling Assess. 2016, 21, 53-69. [CrossRef]

23. Vaskina, I.; Plyatsuk, L.; Vaskin, R.; Ablieieva, I.; Sydorenko, S. Patterns of pollutants distribution from vehicles to the roadside ecosystems. Lect. Notes Mech. Eng. 2020, 893-902. [CrossRef]

24. Pongthanaisawan, J.; Sorapipatana, C. Greenhouse gas emissions from Thailand's transport sector: Trends and mitigation options. Appl. Energy 2013, 101, 288-298. [CrossRef]

25. Wang, C.; Cai, W.; Lu, X.; Chen, J. $\mathrm{CO}_{2}$ mitigation scenarios in China's road transport sector. Energy Convers. Manag. 2007, 48, 2110-2118. [CrossRef]

26. Ou, X.; Zhang, X.; Chang, S. Scenario analysis on alternative fuel/vehicle for China's future road transport: Life-cycle energy demand and GHG emissions. Energy Policy 2010, 38, 3943-3956. [CrossRef]

27. Egede, P.; Dettmer, T.; Hermann, C.; Kara, S. Life Cycle Assessment of Electric Vehicles-A Framework to Consider Influencing Factors. Procedia CIRP 2015, 29, 233-238. [CrossRef]

28. Jing, W.; Yadan, Y.; Kim, I.; Sarvi, M. Electric vehicles: A review of network modelling and future research needs. Adv. Mech. Eng. 2016. [CrossRef]

29. European Environment Agency Report No 21/201-EMEP/EEA air pollutant emission inventory guidebook 2016. In Technical Guidance to Prepare National Emission Inventories; European Environment Agency: Copenhagen, Denmark, 2016. [CrossRef]

30. European Commission. Eurostat Regional Yearbook-Transport Statistics at Regional Level; Imprimerie Bietlot: Charleroi, Belgium, 2019. [CrossRef]

31. International Car Distribution Program (ICDP): Automotive Distribution Research, Insight, Implementation. Available online: https://www.icdp.net/ (accessed on 2 April 2020).

32. Automobile Club Italia (ACI)—Database. Available online: http://www.aci.it/laci/studi-e-ricerche/dati-estatistiche/open-data.html (accessed on 2 April 2020).

33. European Union, Regulation (EU) 2019/631 of the European Parliament and of the Council of 17 April 2019 Setting CO2 Emission Performance Standards for New Passenger Cars and for New Light Commercial Vehicles; Official Journal of the European Union, L 111/13; Publications Office of the European Union: Luxembourg, 2019.

(C) 2020 by the authors. Licensee MDPI, Basel, Switzerland. This article is an open access article distributed under the terms and conditions of the Creative Commons Attribution (CC BY) license (http://creativecommons.org/licenses/by/4.0/). 